\title{
Effect of Phase Transformation on Stress Corrosion Behavior of Additively Manufactured Austenitic Stainless Steel Produced by Directed Energy Deposition
}

\author{
Tomer Ron*(D), Ohad Dolev, Avi Leon (D), Amnon Shirizly (D) and Eli Aghion (i) \\ Department of Materials Engineering, Ben-Gurion University of the Negev, \\ Beer-Sheva 8410501, Israel; dolev.ohad@gmail.com (O.D.); avileon12@gmail.com (A.L.); \\ a.shirizly@gmail.com (A.S.); egyon@bgu.ac.il (E.A.) \\ * Correspondence: toron@post.bgu.ac.il
}

Citation: Ron, T.; Dolev, O.; Leon, A.; Shirizly, A.; Aghion, E. Effect of Phase Transformation on Stress Corrosion Behavior of Additively Manufactured Austenitic Stainless Steel Produced by Directed Energy Deposition. Materials 2021, 14, 55. https://dx.doi.org/10.3390/ ma14010055

Received: 23 November 2020 Accepted: 21 December 2020 Published: 24 December 2020

Publisher's Note: MDPI stays neutral with regard to jurisdictional claims in published maps and institutional affiliations.

Copyright: () 2020 by the authors. Licensee MDPI, Basel, Switzerland. This article is an open access article distributed under the terms and conditions of the Creative Commons Attribution (CC BY) license (https: / creativecommons.org/ licenses/by/4.0/).

\begin{abstract}
The present study aims to evaluate the stress corrosion behavior of additively manufactured austenitic stainless steel produced by the wire arc additive manufacturing (WAAM) process. This was examined in comparison with its counterpart, wrought alloy, by electrochemical analysis in terms of potentiodynamic polarization and impedance spectroscopy and by slow strain rate testing (SSRT) in a corrosive environment. The microstructure assessment was performed using optical and scanning electron microscopy along with X-ray diffraction analysis. The obtained results indicated that in spite of the inherent differences in microstructure and mechanical properties between the additively manufactured austenitic stainless steel and its counterpart wrought alloy, their electrochemical performance and stress corrosion susceptibility were similar. The corrosion attack in the additively manufactured alloy was mainly concentrated at the interface between the austenitic matrix and the secondary ferritic phase. In the case of the counterpart wrought alloy with a single austenitic phase, the corrosion attack was manifested by uniform pitting evenly scattered at the external surface. Both alloys showed ductile failure in the form of "cap and cone" fractures in post-SSRT experiments in corrosive environment.
\end{abstract}

Keywords: additive manufacturing; direct energy deposition; wire arc additive manufacturing; 316L stainless steel; stress corrosion

\section{Introduction}

Additive manufacturing (AM) has been considered to be a promising technology for producing a variety of complex components in a relatively short time [1-6]. Traditional AM processing of metals mainly focuses on powder bed fusion (PBF) methods such as selective laser melting (SLM) and electron beam melting (EBM) [7-10]. However, PBF technologies are relatively expensive due to the high cost of raw material, high energy consumption and relatively low deposition rate. In addition, the size of the printed component is limited and depends on the printing cell dimension. The inherent disadvantages of PBF technologies highlight the need to use more affordable AM methods such as the wire arc additive manufacturing (WAAM) process. Comparatively, proven PBF technologies can produce a deposition rate of $0.1 \mathrm{~kg} / \mathrm{h}$, while the deposition rate of WAAM is about $10 \mathrm{~kg} / \mathrm{h}$ [11-13]. In addition, the use of relatively inexpensive wires as raw materials and an electric arc as the energy source can reduce the cost of the printing process by $80 \%$ compared to PBF [14,15]. Furthermore, the dimensions of components produced by WAAM are almost unlimited [16]. It should be pointed out that WAAM process can be also implemented using computer numerical control (CNC) systems [17]. The almost unlimited dimensions of WAAM is due to the fact that the printing process can be performed by an external robot that is free to move in all directions [18-20]. However, there are some limitations related to the WAAM process compared to PBF technology. This includes relatively increased surface roughness, 
and limited capabilities to produce complex structures. Currently, most of the research activities related to the WAAM process have focused on optimizing the printing parameters and residual stresses status [21-25], with very limited attention paid to the corrosion performance of the obtained components. This study mainly aims at evaluating the effect of phase transformation on stress corrosion behavior of additively manufactured austenitic stainless steel in the form of 316L alloy produced by the WAAM process. For reference consideration, the obtained stress corrosion behavior was compared to its counterpart wrought alloy AISI 316L. The general corrosion performance was evaluated in terms of potentiodynamic polarization and electrochemical impedance spectroscopy (EIS) analyses all in $3.5 \% \mathrm{NaCl}$ solution.

\section{Materials and Methods}

The tested specimens were machined from a hollow cylindrical component produced by the WAAM process with a conventional metal inert gas (MIG) welding system, using austenitic 316L stainless steel welding wire, as shown in Figure 1 [20] along with a tension specimen. No additional heat treatment was applied and all tested were carried out in as-build conditions. The welding wire diameter was $1.14 \mathrm{~mm}$ and the dimensions of the cylindrical component were: $120 \mathrm{~mm}$ height, $55 \mathrm{~mm}$ mid-wall radius and $15 \mathrm{~mm}$ wall thickness. The wire deposition was implemented using a Cloos Rotrol V7.13 robot (CLOOS, Haiger, Germany) that was integrated with a welding head system. The welding pathway was controlled by a computer-aided design (CAD) model. The welding parameters in terms of the deposition process included: wire feed rate of $6.1 \mathrm{~m} / \mathrm{min}$, electrical current of $210 \mathrm{~A}$, voltage of 23.9-24.1 V, pulse frequency of $120 \mathrm{~Hz}$, and robot deposition speed of $14 \mathrm{~cm} / \mathrm{min}$. The deposition process was carried out under a protective gas atmosphere composed of $98 \%$ Argon and $2 \%$ Oxygen. The printing parameters were selected based on regular welding conditions used by MIG-welding of steels.

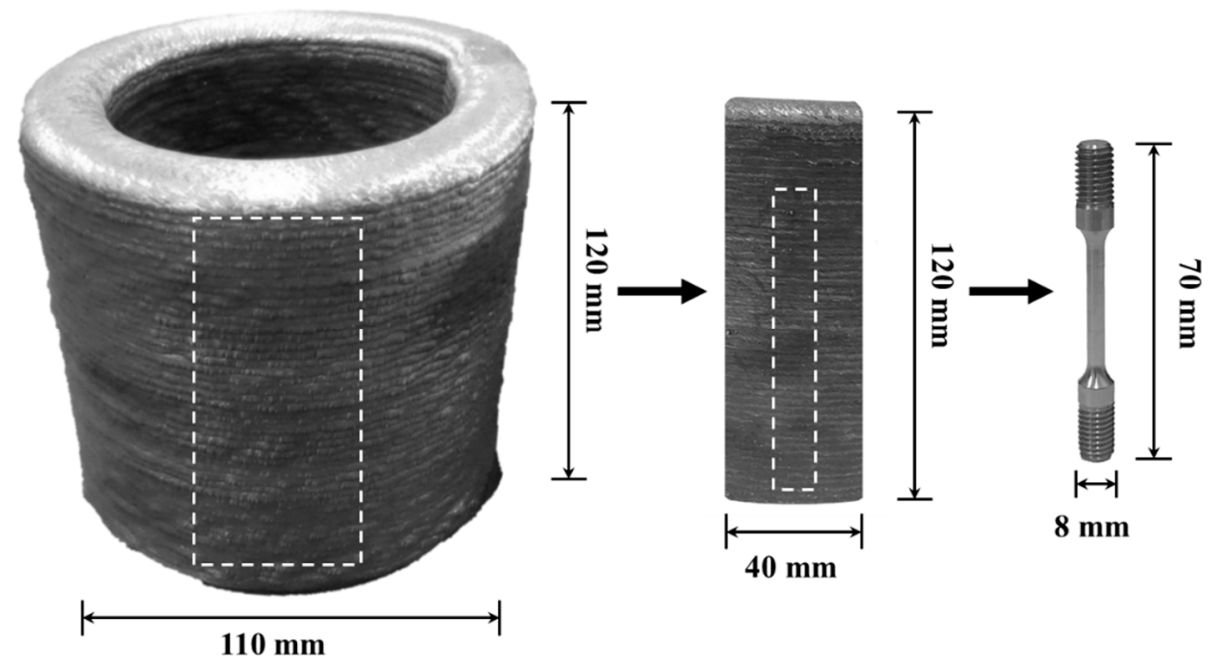

Figure 1. General appearance of the cylindrical component along with a tension specimen obtained by the WAAM process.

Microstructure analysis was carried out by scanning electron microscopy (SEM-JEOL 5600, JEOL Ltd., Tokyo, Japan) [26] equipped with an EDS sensor (Thermo Fisher Scientific, Waltham, MA, USA) for phase chemical composition detection. The metallographic preparation included polishing up to $0.04 \mu \mathrm{m}$ and subsequent etching with $\mathrm{HNO}_{3}(70 \%) 20 \mathrm{~mL}$, $\mathrm{HCl}(32 \%) 45 \mathrm{~mL}$ and ethanol $25 \mathrm{~mL}$ for $1.5 \mathrm{~min}$. The presence of a secondary phase in the form of ferrite (BCC) was evaluated by X-ray diffraction analysis using a RIGAKU-2100H $X$-ray diffractometer (Rigaku Corporation, Tokyo, Japan) with $\mathrm{CuK} \alpha$ [27]. The diffraction parameters were $40 \mathrm{KV} / 30 \mathrm{~mA}$ and a scanning rate of $2^{\circ} / \mathrm{min}$. 
The corrosion performance was examined in terms of electrochemical analysis by potentiodynamic polarization and EIS using a Bio-Logic SP-200 potentiostat (BioLogic Science Instruments, Seyssinet-Pariset, France) equipped with EC-Lab software v11.18. Both analyses were implemented using a standard three-electrode cell with saturated calomel (SCE) as a reference electrode and Platinum as an auxiliary electrode. The potentiodynamic polarization scanning rate was $0.5 \mathrm{mV} / \mathrm{s}$, and the EIS examination was performed between $10 \mathrm{kHz}$ and $0.015 \mathrm{~Hz}$ at a $10 \mathrm{mV}$ amplitude signal. The preparation procedure of the samples for the electrochemical testing included cleaning in an ultrasonic bath for $5 \mathrm{~min}$, washing with alcohol and drying in air. The stress corrosion behavior in terms of SSRT was examined according to ASTM G129-00 standard [28], using Cormet C-76 apparatus (Cormet Testing Systems, Vantaa, Finland) [29,30]. The dimensions of the SSRT test samples were: gauge length $25.4 \mathrm{~mm}$ and cylindrical cross section $11.4 \mathrm{~mm}^{2}$. The SSRT strain rates were: $2.5 \times 10^{-7}, 2.5 \times 10^{-6}$ and $2.5 \times 10^{-5} \mathrm{~s}^{-1}$. All the corrosion tests were carried out in $3.5 \% \mathrm{NaCl}$ solution at ambient temperature $\left(25^{\circ} \mathrm{C}\right)$.

\section{Results}

The chemical composition of the welding wire, printed alloy and counterpart AISI 316L stainless steel alloy are shown in Table 1. This reveals that the composition of the printed alloy was in line with the composition of the welding wire and quite similar to that of the counterpart AISI alloy in terms of main alloying elements and carbon content.

Table 1. Chemical composition (wt.\%) of welding wire, printed stainless steel part and counterpart AISI 316L.

\begin{tabular}{ccccccccccccc}
\hline Material & $\mathbf{C}$ & $\mathbf{M n}$ & $\mathbf{S i}$ & $\mathbf{S}$ & $\mathbf{P}$ & $\mathbf{C r}$ & $\mathbf{N i}$ & $\mathbf{C u}$ & $\mathbf{M o}$ & $\mathbf{C o}$ & $\mathbf{N}$ & $\mathbf{F e}$ \\
\hline Welding Wire & 0.013 & 1.97 & 0.51 & 0.0010 & 0.018 & 19.22 & 11.50 & 0.15 & 2.42 & 0.07 & 0.092 & Bal. \\
Printed 316L & 0.024 & 1.85 & 0.44 & 0.0007 & 0.020 & 19.21 & 11.62 & 0.09 & 2.48 & 0.26 & 0.052 & Bal. \\
AISI 316L & 0.021 & 1.59 & 0.40 & 0.02 & 0.037 & 16.58 & 10.07 & 0.44 & 2.04 & 0.19 & 0.078 & Bal. \\
\hline
\end{tabular}

X-ray diffraction analysis of the printed alloy and its counterpart AISI 316L are shown in Figure 2. This reveals that the printed alloy was composed from an austenitic matrix $(\gamma-\mathrm{Fe})$ and a secondary ferritic phase $(\delta-\mathrm{Fe})$, as expected from a regular 316L printed alloy [31] while the stock material (wire) has one austenitic phase. In parallel, the counterpart AISI 316L was composed from only an austenitic phase. In addition, significant differences were obtained between the XY-plane (building direction $0^{\circ}$ ) and XZ-plane (building direction $90^{\circ}$ ) of the printed alloy in terms of peak intensity. This can be attributed to the epitaxial characteristics of the AM process that display a preferred orientation of the solidification process. The calculated lattice parameter of the $\gamma$-Fe and $\delta$-Fe related to the printed alloy were 2.88 and $3.59 \AA$, respectively, which basically comes in line with the parameters found in the literature: $2.86 \AA$ (PDF 006-096) and 3.59 $\AA$ (PDF 33-0397). In the case of the counterpart AISI $316 \mathrm{~L}$, the calculated lattice parameter was $3.59 \AA$, as expected. Furthermore, it should be pointed out that, in contrast to the microstructure of 316L obtained by the WAAM process as presented by X. Chen et al. [25,32], no $\sigma$-phase was observed in this study.

Typical microstructure of printed 316L stainless steel in the XY- and XZ-planes is shown in Figure 3 while the microstructure of its counterpart AISI 316L alloy is introduced in Figure 4. The microstructure of the printed alloy was composed from an austenitic matrix and a secondary ferritic phase at the grain boundaries. The ferritic dendrites in the XY-plane present an anisotropic morphology, while the XZ-plane introduces an epitaxial solidification characteristic. In parallel, the counterpart AISI 316L was composed of a single austenitic phase, as expected from conventional 316L stainless steel [33]. The two-phase microstructure of the printed alloy was formed due to the high solidification rate of the AM process. This can also be explained in terms of the Fe-Cr-Ni phase diagram [34] operating under high cooling rate conditions. In addition, the inherent re-heating effect of the AM 
process produces a non-equilibrium microstructure that displays the presence of a primary $\delta$ ferrite phase [25].

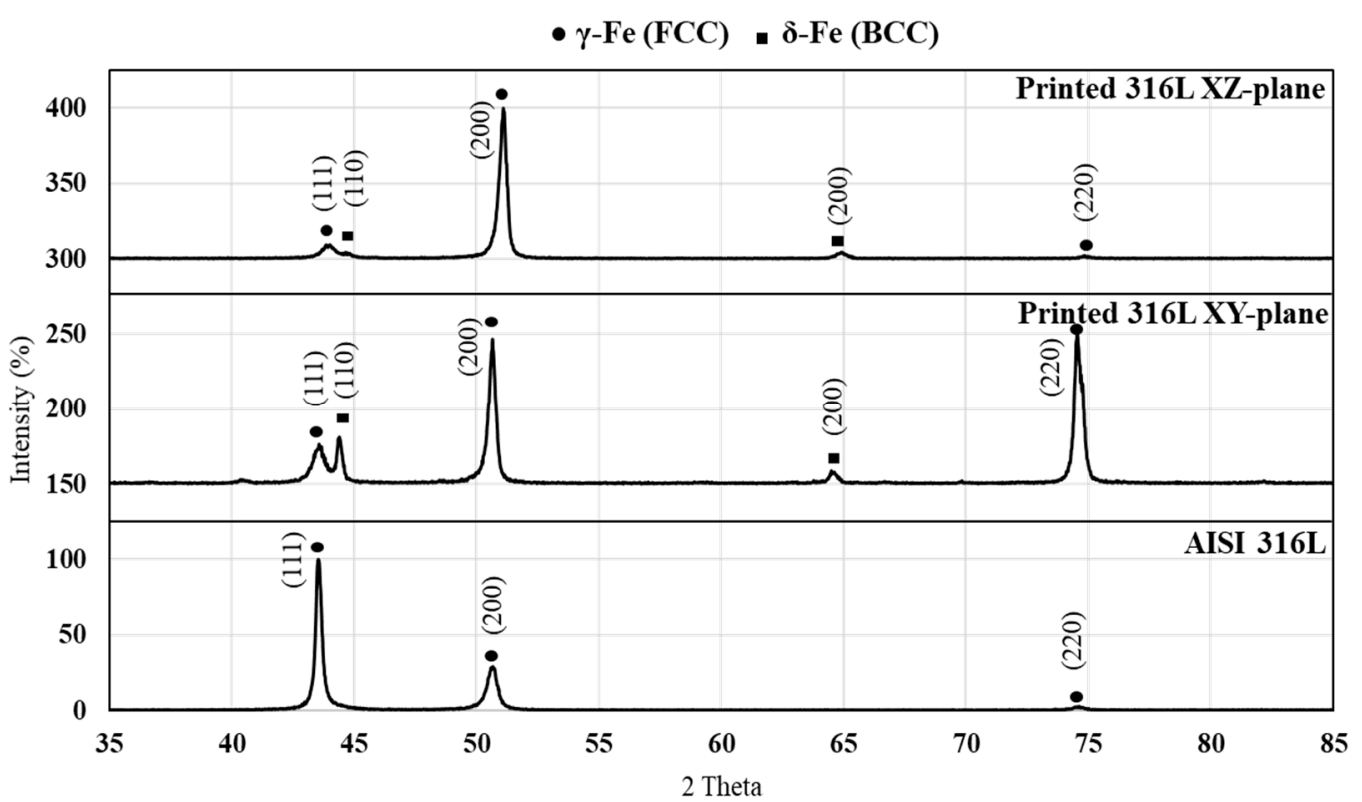

Figure 2. X-ray diffraction analysis of printed alloy and AISI 316L alloy.
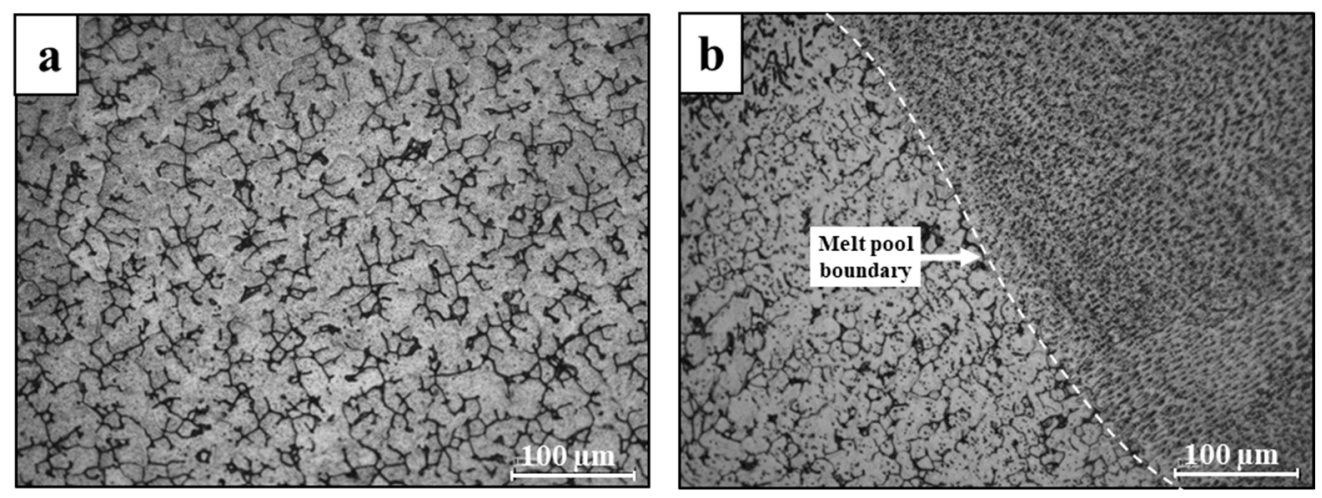

Figure 3. Typical microstructures of printed 316L stainless steel obtained by optical microscopy (a) XY-plane, (b) XZ-plane.
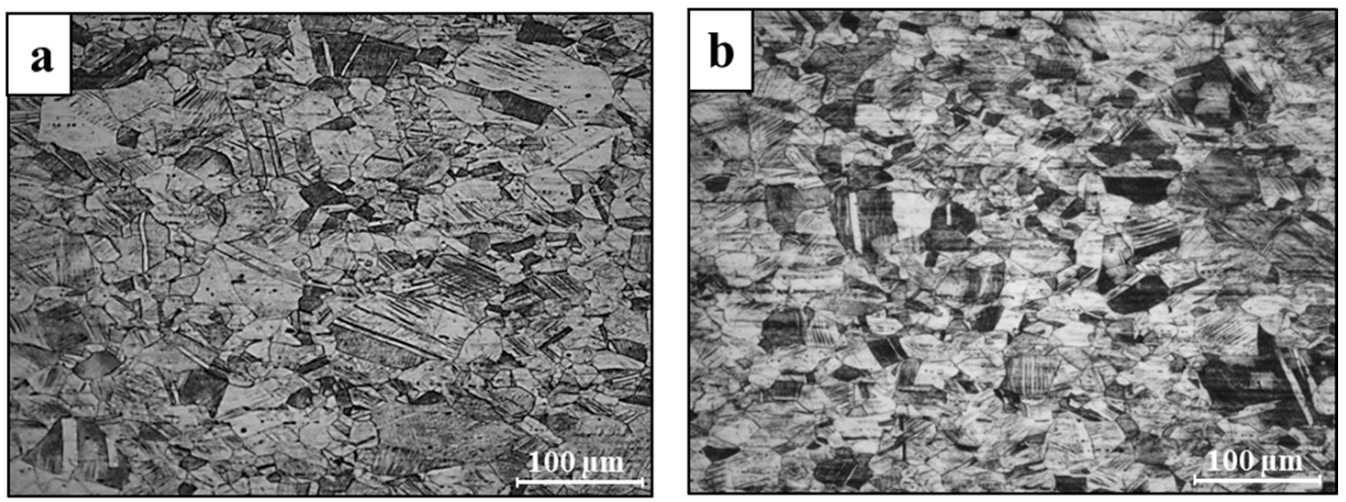

Figure 4. Typical microstructures of AISI 316L stainless steel (a) longitudinal cross section, (b) transvers cross section.

The general macrostructure of the printed alloy in 3D is shown in Figure 5, along with the corresponding close-up microstructures and spot chemical analysis. This clearly reveals 
that the microstructure in the XY-plane was quite uniform compared to the non-uniform structure in the XZ-plane that relates to the preferred orientation of the solidification course. In addition, the melt pool boundaries shown in Figure 5d,e clearly illustrate the epitaxial nature of solidification in the XZ-plane. The spot chemical analyses at points 1 and 2 (Table 2) disclose the typical compositions of austenite and ferrite phases, respectively. These compositions reflect the relatively increased amount of $\mathrm{Ni}$ and reduced content of $\mathrm{Cr}$ in the austenitic phase and vice versa in the ferritic phase.
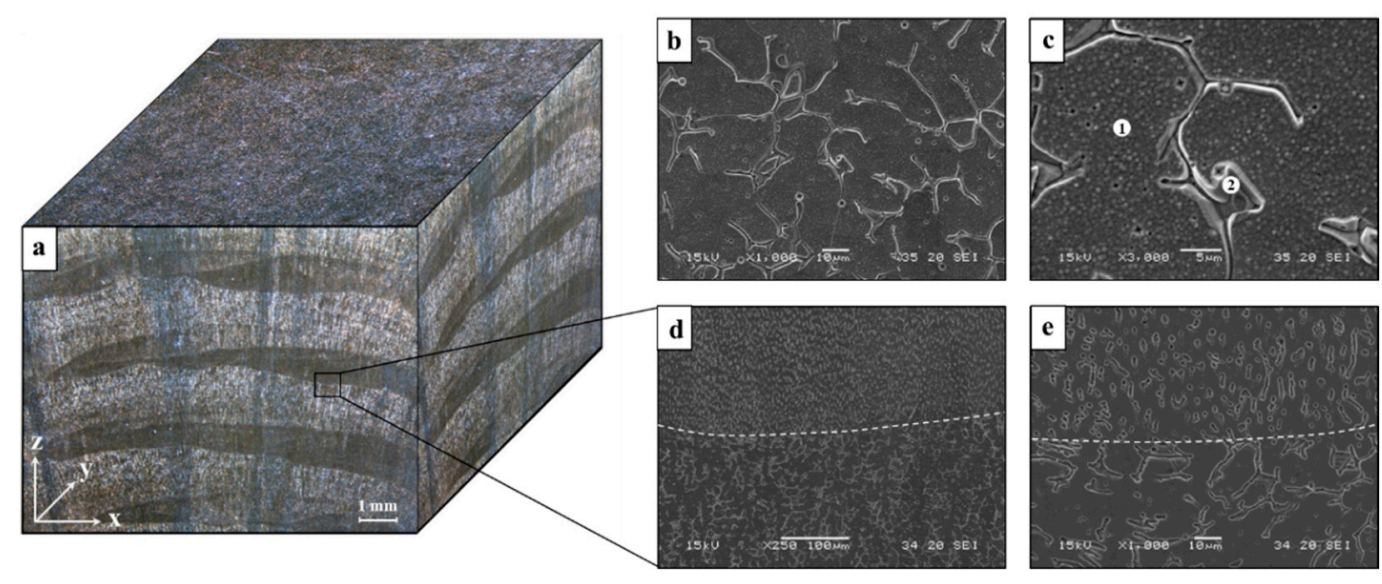

Figure 5. Macrostructure and corresponding microstructures of printed 316L alloy obtained by stereo microscope and SEM (a) general macrostructure, $(\mathbf{b}, \mathbf{c})$ microstructure in the XY-plane, $(\mathbf{d}, \mathbf{e})$ microstructure in the XZ-plane.

Table 2. Spot chemical analysis of printed 316L at points 1 and 2 (Figure 5c) by EDS in wt.\%.

\begin{tabular}{cccccccc}
\hline $\begin{array}{c}\text { Test } \\
\text { Point }\end{array}$ & C & Mn & Si & Cr & Ni & Mo & Fe \\
\hline Point 1 & 0.39 & 2.3 & 0.41 & 17.34 & 12.08 & 2.02 & Bal. \\
Point 2 & 0.25 & 2.12 & 0.39 & 24.86 & 5.43 & 4.17 & Bal. \\
\hline
\end{tabular}

The mechanical properties of printed 316L and its counterpart AISI 316L in terms of tensile strength, yield strength, elongation and hardness are shown in Table 3 along with their typical stress-strain curves shown in Figure 6. This reveals that the strength of the printed alloy was relatively reduced, while its ductility was increased compared to the counterpart AISI 316L.

Table 3. The mechanical properties_UTS (Ultimate tensile strength), YP (yield point) elongation, hardness and density of printed and AISI 316L stainless steel.

\begin{tabular}{|c|c|c|c|c|c|}
\hline Material & UTS (MPa) & YP (MPa) & Elongation (\%) & Hardness (HV) & Density $\left(\mathrm{gr} / \mathrm{cm}^{3}\right)$ \\
\hline Printed 316L & $552 \pm 11$ & $364 \pm 17$ & $42 \pm 1$ & $196 \pm 5$ & $7.6 \pm 0.3$ \\
\hline AISI 316L & $752 \pm 3$ & $695 \pm 3$ & $37 \pm 1$ & $275 \pm 9$ & $7.8 \pm 0.2$ \\
\hline
\end{tabular}

The corrosion resistance of the printed and counterpart AISI 316L in terms of potentiodynamic polarization analysis is shown in Figure 7. Although the polarization curve of the printed alloy was relatively shifted to higher corrosion currents, which reflects reduced corrosion resistance $[35,36]$, its break potential $\left(E_{\mathrm{b} 1}\right)$ was relatively higher compared to the AISI 316L $\left(E_{\mathrm{b} 2}\right)$, which reflects an improved passivation process. Altogether, the corrosion rate of the printed alloy in terms of Tafel extrapolation was excellent, and quite similar to the counterpart alloy as shown in Table 4 (0.005 vs. $0.001 \mathrm{mmpy}$, respectively). In addition, as expected from metals having an active-passive transition, both alloys showed localized corrosion attack. In the case of the printed alloy the localized corrosion attack was concentrated at the boundaries between the austenite and ferrite phases (Figure 8a,b) [37]. 
The corrosion attack in the counterpart AISI 316L was in the form of pitting corrosion (Figure $8 \mathrm{c}, \mathrm{d}$ ) that was evenly scattered on the external surface. The counterpart alloy presented typical pitting morphology for AISI 316L, as well as typical corrosion potential, breakdown potential and corrosion current [38].

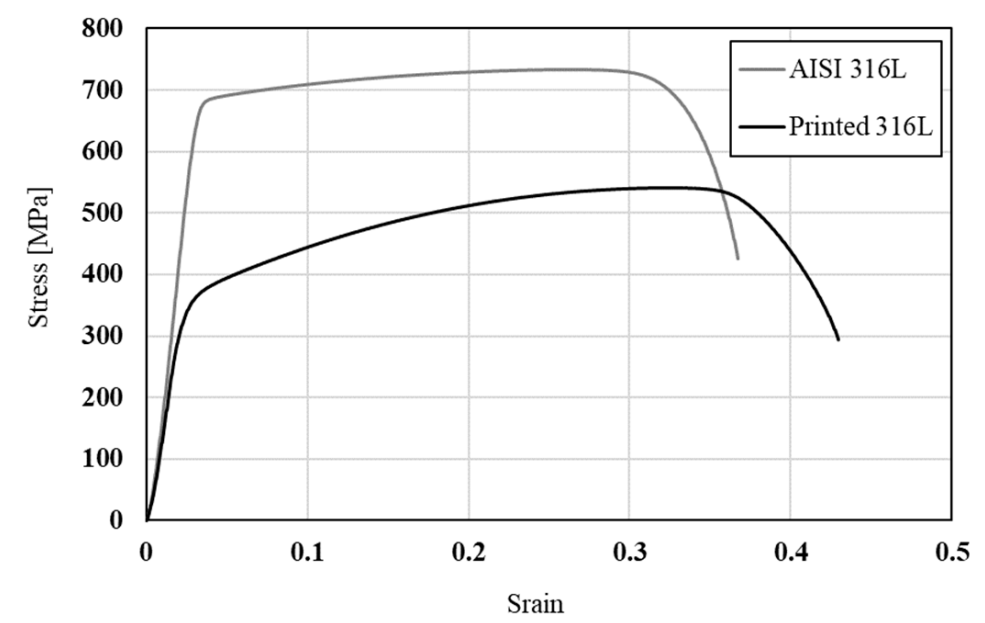

Figure 6. Typical stress-strain curves of printed 316L alloy and counterpart AISI 316L.

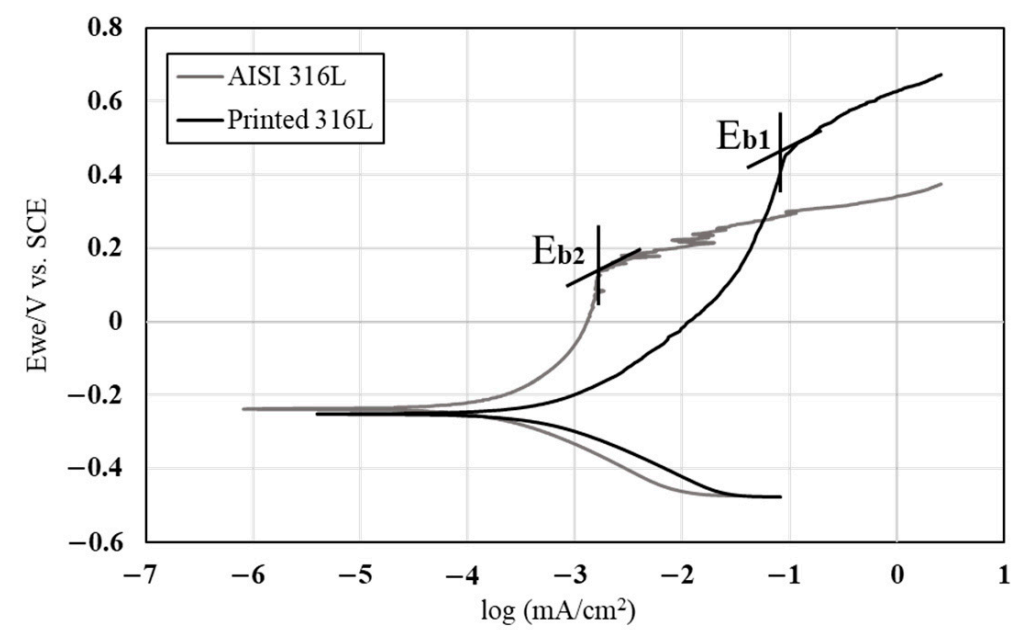

Figure 7. Potentiodynamic polarization analysis of printed 316L alloy and counterpart AISI 316L in $3.5 \% \mathrm{NaCl}$ solution.

Table 4. Corrosion rate of tested alloys as obtained by Tafel extrapolation from potentiodynamic polarization curves.

\begin{tabular}{ccccc}
\hline Material & $\boldsymbol{E}_{\text {corr }}(\mathbf{v})$ & $\begin{array}{c}\boldsymbol{I}_{\text {corr }} \\
\left(\boldsymbol{\mu} \mathbf{A} / \mathbf{c m}^{2}\right)\end{array}$ & $\begin{array}{c}\text { Corrosion Rate } \\
(\mathbf{m m p y})\end{array}$ & $\begin{array}{c}E_{\text {break }} \\
(\mathbf{v})\end{array}$ \\
\hline Printed 316L & $-0.25 \pm 0.02$ & $0.48 \pm 0.12$ & $0.005 \pm 0.001$ & $0.47 \pm 0.03$ \\
AISI 316L & $-0.21 \pm 0.02$ & $0.09 \pm 0.004$ & $0.001 \pm 0.0003$ & $0.18 \pm 0.004$ \\
\hline
\end{tabular}

The corrosion performance of printed and AISI 316L obtained by EIS analysis are shown in Figure 9. The Nyquist diagrams of both alloys (Figure 9a) in terms of curve radius, which represents the surface corrosion resistance, were quite similar. This similarity was also maintained by the Bode magnitude diagram (Figure $9 \mathrm{~b}$ ) that introduces the solution resistance. The related electrical equivalent circuit and corresponding fitting parameters (R1solution resistance, R2 and Q1-capacitor) [39,40] are introduced in Figure 10 and Table 5, respectively. Altogether, the EIS analysis clearly indicates that the corrosion resistance of printed and counterpart alloys was quite similar. 

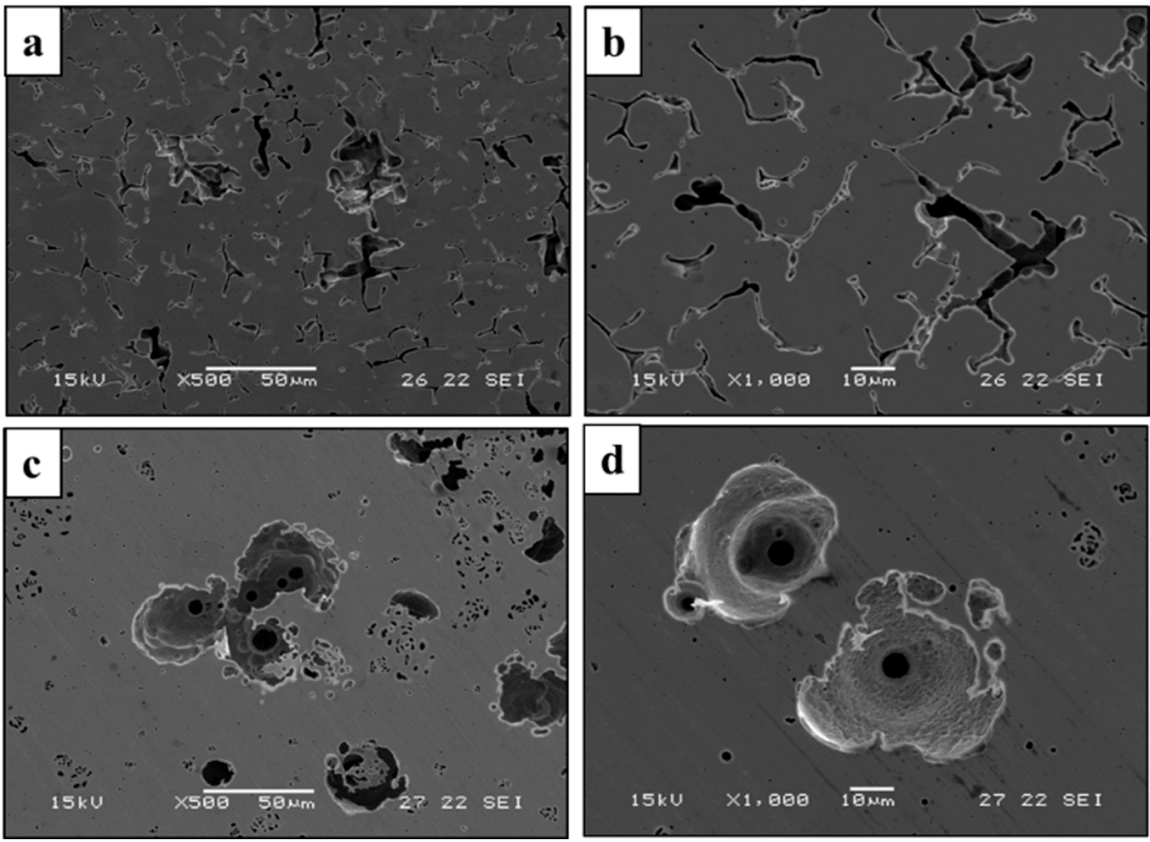

Figure 8. (a,b) Close-up views of the corrosion attack at surface of printed alloy, (c,d) close-up views of the corrosion attack at surface of counterpart AISI alloy.
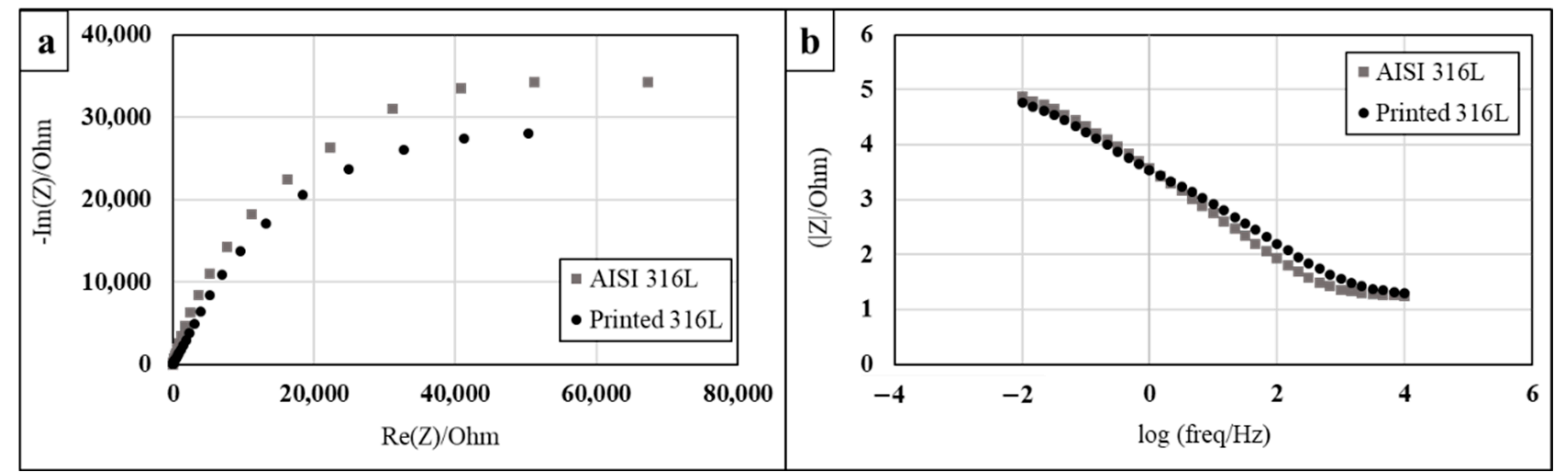

Figure 9. Electrochemical impedance spectroscopy analysis of printed and AISI 316L in 3.5\% NaCl solution: (a) Nyquist diagram, (b) Bode diagram.

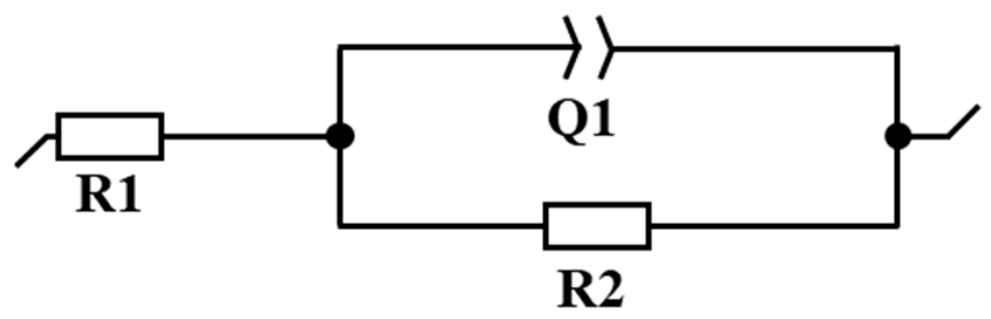

Figure 10. Electrical equivalent circuits for the EIS analysis shown in Figure 9.

Table 5. Corresponding fitting parameters for the EIS analysis shown in Figure 9.

\begin{tabular}{ccccc}
\hline Material & R1 (Ohm) & Q1 (F. $\mathbf{s}^{\mathbf{a}-\mathbf{1})}$ & $\mathbf{a}$ & $\mathbf{R 2 ~ ( O h m ) ~}$ \\
\hline Printed 316L & 15.6 & $7.31 \times 10^{-5}$ & 0.705 & 92,178 \\
AISI 316L & 16.98 & $6.07 \times 10^{-5}$ & 0.825 & 83,863 \\
\hline
\end{tabular}


The stress corrosion behavior of the printed and counterpart AISI 316L in terms of SSRT in $3.5 \% \mathrm{NaCl}$ solution, are shown in Figures 8-10. Although the stress corrosion performance of the two alloys was similar, as reflected by nearly equal time to failure vs. strain rate (Figure 11), the two alloys maintain their inherent UTS and elongation properties (Figures 12 and 13, respectively). This similarity could also be seen by the fitting equations $\left(\sigma_{\text {UTS }}=C \times \dot{\varepsilon}^{\mathrm{m}}\right)$ of UTS vs. strain rate According to these fittings, the stain rate sensitively factors $(m)$ of the two alloys were very close: 0.007 and 0.009 for the printed and AISI 316L, respectively. Fractography analysis of the two alloys (Figure 14a-d) clearly demonstrates that both alloys showed ductile failure behavior in the form of "cap and cone" fractures, as expected from 316L stainless steel alloy.

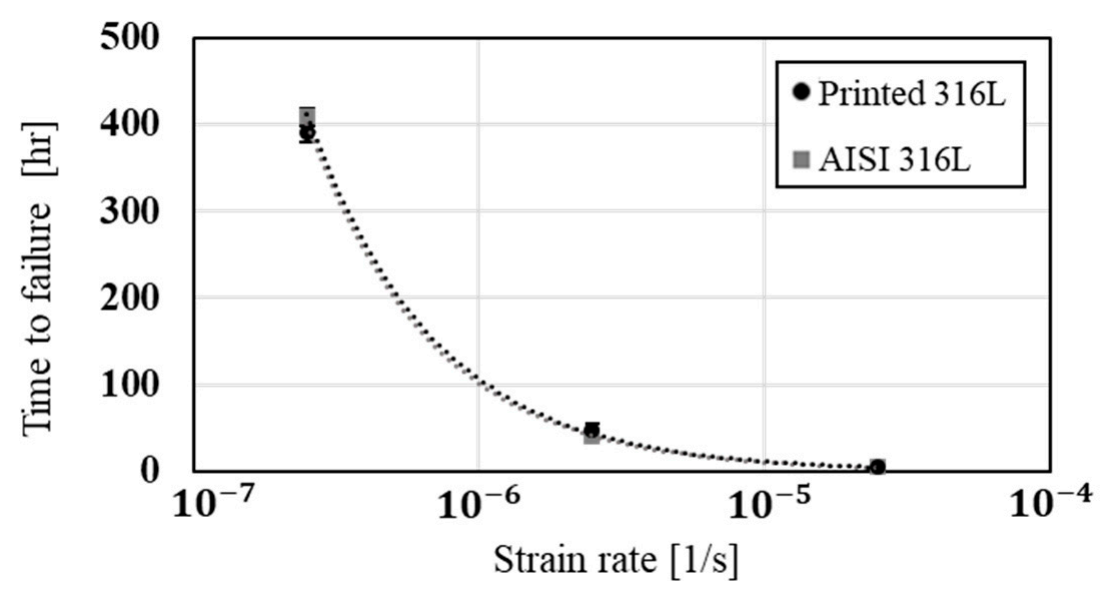

Figure 11. The effect of strain rate on time to failure of 316L produced by WAAM process in comparison with conventional wrought alloy AISI 316L.

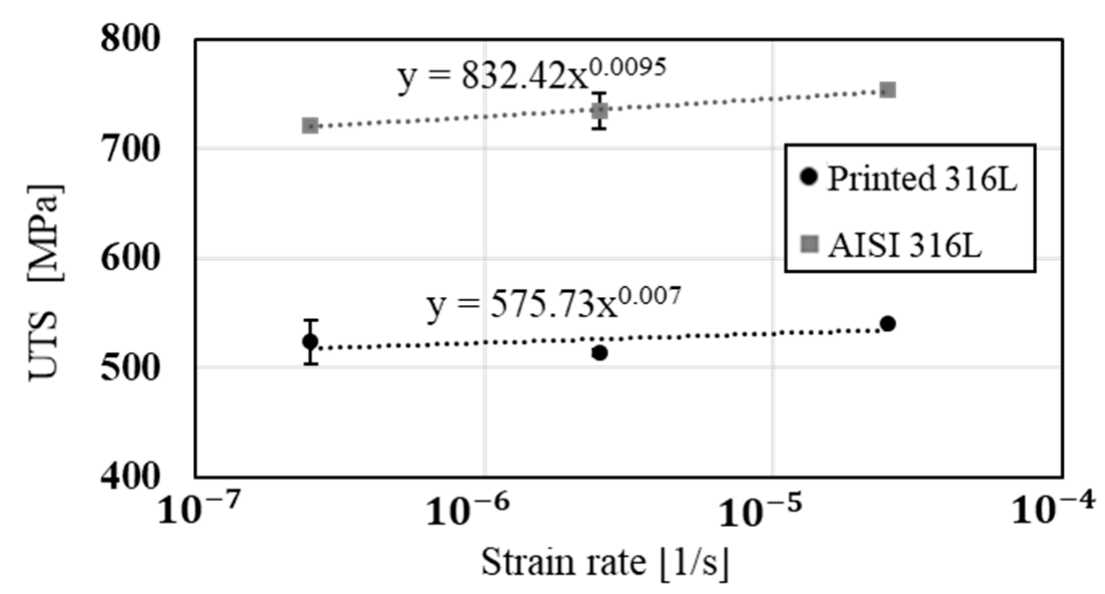

Figure 12. Ultimate tensile strength (UTS) versus strain rate of 316L produced by WAAM process compared to its counterpart wrought alloy AISI 316L. 


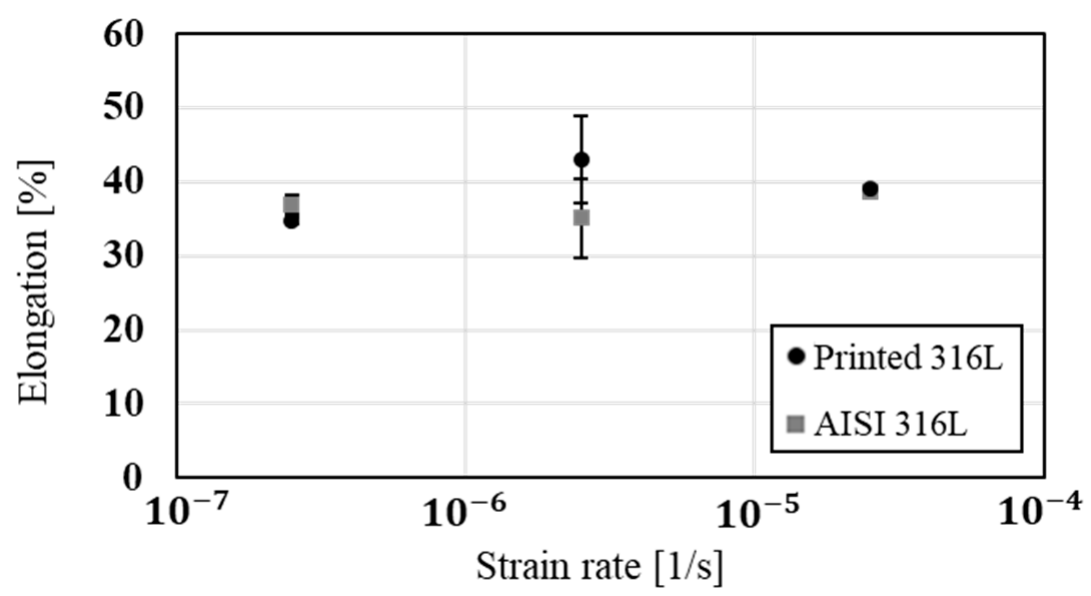

Figure 13. Ductility in terms of elongation versus strain rate of 316L produced by WAAM process compared to wrought alloy AISI 316L.
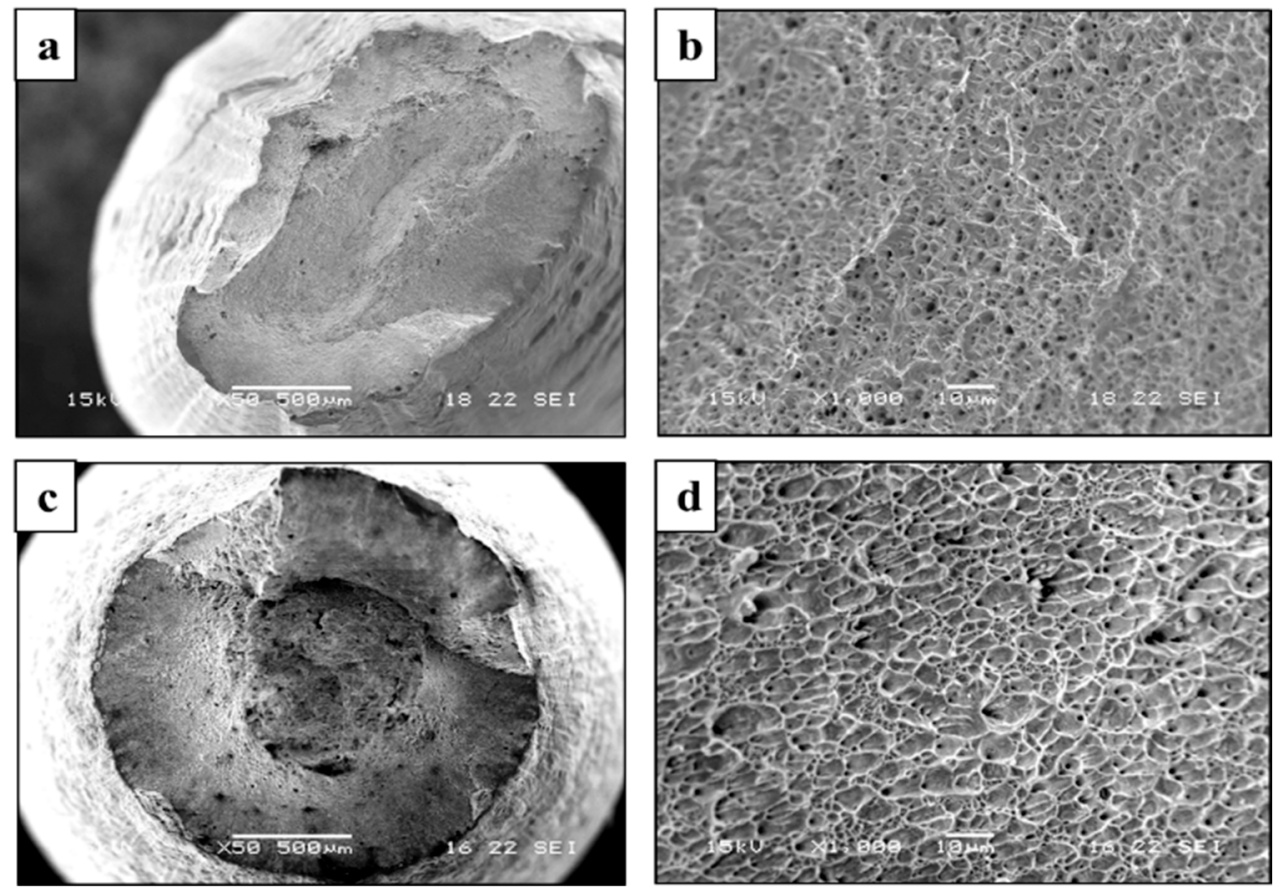

Figure 14. Fracture surface after SSRT at a strain rate of $2.5 \times 10^{-7}(1 / \mathrm{S})$ in $3.5 \% \mathrm{NaCl}$ solution. (a,b) printed alloy, (c,d) counterpart AISI 316L.

\section{Discussion}

In spite of the differences between the microstructure and mechanical properties of WAAM 316L alloy and its counterpart AISI 316L, their corrosion performance in 3.5\% $\mathrm{NaCl}$ solution was quite similar. This was strongly supported by the results of potentiodynamic polarization, EIS and stress corrosion analysis in terms of SSRT examination. Nevertheless, the corrosion mechanism of the two alloys was slightly different. This was clearly demonstrated by the surface corrosion attack shown in Figure 8. According to this figure, the localized corrosion attack in the printed alloy was mainly located at the interface between the austenitic matrix and the secondary ferritic phase (Figure 8a,b). This was mainly attributed to the relatively reduced corrosion resistance of the ferritic phase compared to the austenitic phase, which can induce micro-galvanic corrosion. In the case of the counterpart AISI 316L, the localized corrosion attack was in the form of pitting corrosion that was uniformly scattered on the surface (Figure $8 c, d$ ). 
Regarding the effect of strain rate on UTS and elongation under a corrosive environment, both the printed and the counterpart AISI 316L displayed a similar response, according to their inherent mechanical properties. The similarity in their stress corrosion resistance was demonstrated by nearly equal time to failure at a slow strain rate of $2.5 \times 10^{-7} \mathrm{~s}^{-1}$ (Figure 11), where the environmental effect was most dominant. This similarity was also manifested by the fractography analysis of the two alloys (Figure 14a-d) that clearly showed ductile failure characteristics in the form of "cap and cone" fractures, as can be expected from 316L stainless steel alloy [41].

As a final remark it should be pointed out that the similar corrosion performance of printed WAAM 316 alloy and its counterpart AISI 316 in 3.5\% NaCl solution cannot be simply extrapolated to any different environment. This is mainly due to the inherent differences between the microstructure of the two alloys that can affect their corrosion behavior primarily in a more aggressive environment.

\section{Conclusions}

The stress corrosion behavior of additively manufactured austenitic stainless steel (316L alloy) produced by WAAM process in terms of stress corrosion susceptibility and electrochemical performance was similar to that of its counterpart wrought alloy. This similarity was obtained in spite of the inherent differences in microstructure and mechanical properties of the two alloys. The corrosion attack in the printed alloy was mainly located at the interface between the austenitic matrix and the ferritic phase, while that of the counterpart alloy composed of a single austenite phase was in the form of pitting corrosion uniformly scattered on the surface. The fractography analysis of the two alloys in post-SSRT experiments revealed that both alloys showed ductile failure in the form of "cap and cone" fractures, as expected from austenitic stainless steel.

Author Contributions: E.A., A.S. and T.R. conceived, designed and performed the experiments; A.L. and O.D. assisted in analyzing the data; E.A. and T.R. writing - original draft preparation and writingreview and editing. All authors have read and agreed to the published version of the manuscript.

Funding: This research received no external funding.

Institutional Review Board Statement: Not applicable.

Informed Consent Statement: Not applicable.

Data Availability Statement: Data sharing is not applicable to this article.

Acknowledgments: The authors thank the Kreitman School for Advanced Studies at Ben-Gurion University of the Negev for their financial contribution in support of this research.

Conflicts of Interest: The authors declare no conflict of interest.

\section{References}

1. Leon, A.; Levy, G.K.; Ron, T.; Shirizly, A.; Aghion, E. The effect of strain rate on stress corrosion performance of Ti6Al4V alloy produced by additive manufacturing process. J. Mater. Res. Technol. 2020. [CrossRef]

2. $\quad$ Rodrigues, T.A.; Duarte, V.; Avila, J.A.; Santos, T.G.; Miranda, R.; Oliveira, J. Wire and arc additive manufacturing of HSLA steel: Effect of thermal cycles on microstructure and mechanical properties. Addit. Manuf. 2019, 27, 440-450. [CrossRef]

3. Ding, D.; Pan, Z.; Cuiuri, D.; Li, H. Wire-feed additive manufacturing of metal components: Technologies, developments and future interests. Int. J. Adv. Manuf. Technol. 2015, 81, 465-481. [CrossRef]

4. Leon, A.; Shirizly, A.; Aghion, E. Corrosion Behavior of AlSi10Mg Alloy Produced by Additive Manufacturing (AM) vs. Its Counterpart Gravity Cast Alloy. Metals 2016, 6, 148. [CrossRef]

5. Herzog, D.; Seyda, V.; Wycisk, E.; Emmelmann, C. Additive manufacturing of metals. Acta Mater. 2016, 117, 371-392. [CrossRef]

6. Haghdadi, N.; Laleh, M.; Moyle, M.; Primig, S. Additive manufacturing of steels: A review of achievements and challenges. J. Mater. Sci. 2020, 56, 64-107. [CrossRef]

7. Leon, A.; Levy, G.K.; Ron, T.; Shirizly, A.; Aghion, E. The effect of hot isostatic pressure on the corrosion performance of Ti6Al4V produced by an electron-beam melting additive manufacturing process. Addit. Manuf. 2020, 33, 101039. [CrossRef]

8. Zakay, A.; Aghion, E. Effect of Post-heat Treatment on the Corrosion Behavior of AlSi10Mg Alloy Produced by Additive Manufacturing. JOM 2019, 71, 1150-1157. [CrossRef] 
9. Rodrigues, T.A.; Duarte, V.; Miranda, R.M.; Santos, T.G.; Oliveira, J.P. Current Status and Perspectives on Wire and Arc Additive Manufacturing (WAAM). Materials 2019, 12, 1121. [CrossRef]

10. Ding, D.; Pan, Z.; Cuiuri, D.; Li, H. A multi-bead overlapping model for robotic wire and arc additive manufacturing (WAAM). Robot. Comput. Manuf. 2015, 31, 101-110. [CrossRef]

11. Gisario, A.; Kazarian, M.; Martina, F.; Mehrpouya, M. Metal additive manufacturing in the commercial aviation industry: A review. J. Manuf. Syst. 2019, 53, 124-149. [CrossRef]

12. Donoghue, J.M.; Antonysamy, A.A.; Martina, F.; Colegrove, P.; Williams, S.W.; Prangnell, P. The effectiveness of combining rolling deformation with Wire-Arc Additive Manufacture on $\beta$-grain refinement and texture modification in Ti-6Al-4V. Mater. Charact. 2016, 114, 103-114. [CrossRef]

13. Busachi, A.; Erkoyuncu, J.; Colegrove, P.; Martina, F.; Watts, C.; Drake, R. A review of Additive Manufacturing technology and Cost Estimation techniques for the defence sector. CIRP J. Manuf. Sci. Technol. 2017, 19, 117-128. [CrossRef]

14. Bekker, A.C.M.; Verlinden, J.C.; Galimberti, G. Challenges in assessing the sustainability of wire+ arc additive manufacturing for large structures. In Proceedings of the Solid Freeform Fabrication Symposium, Austin, TX, USA, 8-10 August 2016; pp. 406-418.

15. Cunningham, C.R.; Wikshåland, S.; Xu, F.; Kemakolam, N.; Shokrani, A.; Dhokia, V.; Newman, S. Cost Modelling and Sensitivity Analysis of Wire and Arc Additive Manufacturing. Procedia Manuf. 2017, 11, 650-657. [CrossRef]

16. Ron, T.; Levy, G.K.; Dolev, O.; Leon, A.; Shirizly, A.; Aghion, E. Environmental Behavior of Low Carbon Steel Produced by a Wire Arc Additive Manufacturing Process. Metals 2019, 9, 888. [CrossRef]

17. Bandari, Y.K.; Williams, S.W.; Ding, J.; Martina, F. Additive manufacture of large structures: Robotic or CNC systems. In Proceedings of the 26th international solid freeform fabrication symposium, Austin, TX, USA, 10-12 August 2015; pp. 12-14.

18. Williams, S.W.; Martina, F.; Addison, A.C.; Ding, J.; Pardal, G.; Colegrove, P.A. Wire + Arc Additive Manufacturing. Mater. Sci. Technol. 2016, 32, 641-647. [CrossRef]

19. Ron, T.; Levy, G.K.; Dolev, O.; Leon, A.; Shirizly, A.; Aghion, E. The Effect of Microstructural Imperfections on Corrosion Fatigue of Additively Manufactured ER70S-6 Alloy Produced by Wire Arc Deposition. Metals 2020, 10, 98. [CrossRef]

20. Shirizly, A.; Dolev, O. From Wire to Seamless Flow-Formed Tube: Leveraging the Combination of Wire Arc Additive Manufacturing and Metal Forming. JOM 2018, 71, 709-717. [CrossRef]

21. Derekar, K.S. A review of wire arc additive manufacturing and advances in wire arc additive manufacturing of aluminium. Mater. Sci. Technol. 2018, 34, 895-916. [CrossRef]

22. Wu, B.; Pan, Z.; Ding, D.; Cuiuri, D.; Li, H.; Xu, J.; Norrish, J. A review of the wire arc additive manufacturing of metals: Properties, defects and quality improvement. J. Manuf. Process. 2018, 35, 127-139. [CrossRef]

23. Pan, Z.; Ding, D.; Wu, B.; Cuiuri, D.; Li, H.; Norrish, J. Arc Welding Processes for Additive Manufacturing: A Review; Springer Science and Business Media LLC: Berlin, Germany, 2017; pp. 3-24.

24. Wang, L.; Xue, J.; Wang, Q. Correlation between arc mode, microstructure, and mechanical properties during wire arc additive manufacturing of 316L stainless steel. Mater. Sci. Eng. A 2019, 751, 183-190. [CrossRef]

25. Chen, X.; Li, J.; Cheng, X.; He, B.; Wang, H.; Huang, Z. Microstructure and mechanical properties of the austenitic stainless steel 316L fabricated by gas metal arc additive manufacturing. Mater. Sci. Eng. A 2017, 703, 567-577. [CrossRef]

26. Kaya, A.; Uzan, P.; Eliezer, D.; Aghion, E. Electron microscopical investigation of as cast AZ91D alloy. Mater. Sci. Technol. 2000, 16, 1001-1006. [CrossRef]

27. Aghion, E.; Gueta, Y.; Moscovitch, N.; Bronfin, B. Effect of yttrium additions on the properties of grain-refined Mg-3\%Nd alloy. J. Mater. Sci. 2008, 43, 4870-4875. [CrossRef]

28. Available online: https:/ /www.astm.org/Standards/G129 (accessed on 21 December 2020).

29. Arnon, A.; Aghion, E. Stress Corrosion Cracking of Nano/Sub-micron E906 Magnesium Alloy. Adv. Eng. Mater. 2008, 10, 742745. [CrossRef]

30. Hakimi, O.; Aghion, E.; Goldman, J. Improved stress corrosion cracking resistance of a novel biodegradable EW62 magnesium alloy by rapid solidification, in simulated electrolytes. Mater. Sci. Eng. C 2015, 51, 226-232. [CrossRef]

31. Guo, P.; Zou, B.; Huang, C.; Gao, H. Study on microstructure, mechanical properties and machinability of efficiently additive manufactured AISI 316L stainless steel by high-power direct laser deposition. J. Mater. Process. Technol. 2017, 240, 12-22. [CrossRef]

32. Chen, X.; Li, J.; Cheng, X.; Wang, H.; Huang, Z. Effect of heat treatment on microstructure, mechanical and corrosion properties of austenitic stainless steel 316L using arc additive manufacturing. Mater. Sci. Eng. A 2018, 715, 307-314. [CrossRef]

33. Xiong, J.; Tan, M.Y.; Forsyth, M. The corrosion behaviors of stainless steel weldments in sodium chloride solution observed using a novel electrochemical measurement approach. Desalination 2013, 327, 39-45. [CrossRef]

34. Koseki, T.; Flemings, M.C. Solidification of undercooled Fe-Cr-Ni alloys: Part I. Thermal behavior. Met. Mater. Trans. A 1995, 26, 2991-2999. [CrossRef]

35. Itzhak, D.; Aghion, E. Corrosion behaviour of hot-pressed austenitic stainless steel in $\mathrm{H} 2 \mathrm{SO} 4$ solutions at room temperature. Corros. Sci. 1983, 23, 1085-1094. [CrossRef]

36. Itzhak, D.; Aghion, E. An anodic behaviour study of an analogical sintered system of austenitic stainless steel in $\mathrm{H} 2 \mathrm{SO} 4$ solution. Corros. Sci. 1984, 24, 145-149. [CrossRef]

37. Garcia-Cabezon, C.; Martín, F.; Blanco, Y.; De Tiedra, P.; Aparicio, M. Corrosion behaviour of duplex stainless steels sintered in nitrogen. Corros. Sci. 2009, 51, 76-86. [CrossRef] 
38. Al Saadi, S.; Yi, Y.; Cho, P.; Jang, C.; Beeley, P. Passivity breakdown of 316L stainless steel during potentiodynamic polarization in $\mathrm{NaCl}$ solution. Corros. Sci. 2016, 111, 720-727. [CrossRef]

39. Leon, A.; Aghion, E. Effect of surface roughness on corrosion fatigue performance of AlSi10Mg alloy produced by Selective Laser Melting (SLM). Mater. Charact. 2017, 131, 188-194. [CrossRef]

40. Kafri, A.; Ovadia, S.; Yosafovich-Doitch, G.; Aghion, E. The Effects of 4\%Fe on the Performance of Pure Zinc as Biodegradable Implant Material. Ann. Biomed. Eng. 2019, 47, 1400-1408. [CrossRef]

41. Kubík, P.; Šebek, F.; Petruška, J.; Hůlka, J.; Park, N.; Huh, H. Comparative investigation of ductile fracture with 316L austenitic stainless steel in small punch tests: Experiments and simulations. Theor. Appl. Fract. Mech. 2018, 98, 186-198. [CrossRef] 